\title{
Chromosome numbers of Polish vascular plants (Part 4)
}

\author{
MARTA MIZIANTY, ZBIGNIEW MIREK, LUDWIK FREY
}

Institute of Botany, Polish Academy of Sciences, Lubicz 46, 31-512 Kraków, Poland (Received: March 23, 1983. Revision accepted: May 30, 1983)

\begin{abstract}
The authors give results of karyological studies carried out on 20 species of vascular plants from Poland. Most of the results are reported for the first time for this country. The chromosome number of Gnaphalium hoppeanum $2 \mathrm{n}=28$ was established for the first time.
\end{abstract}

Key words: chromosome numbers, Polish plants.

\section{INTRODUCTION}

The present paper concerns the chromosome numbers of twenty vascular plants of the Polish flora. The present is the fourth consecutive paper and it is a continuation of our previous studies on chromosome numbers (Frey et al. 1977, Mizianty et al. 1981, Frey et al. 1981).

\section{MATERIAL AND METHODS}

Most of the mentioned species are relatively rare or very rare ones in our country, e. g. Barbarea intermedia, Echinops sphaerocephalus, Geranium pyrenaicum, Iva xanthifolia, Malva moschata, Spergula maxima. That is why the material for study has been collected from single localities only.

All the investigated plants were collected exclusively in natural habitats. Determinations of chromosome numbers were made in root-tip metaphases of adult plants as well as seedlings. Materials were pretreated with a saturated solution of 1-bromonaphthalene or with $0.3 \%$ colchicine solution. They were then fixed in glacial acetic acid-alcohol (1:3) and squashed in $2-3 \%$ acetocarmine. 
Chromosome numbers were established by M. Mizianty and L. F r e y. Plant collection, taxonomic comments and determination were made by $\mathrm{Z}$. Mire k.

\section{RESULTS}

\section{POLYGONACEAE}

\section{Rumex alpinus L., $2 \mathrm{n}=20$ (Fig. 1)}

Widespread usually in lower and upper mountain zone. The plants examined in the course of the present paper were collected in Niżnia Polana Kominiarska (Western Tatra Mts.), $1180 \mathrm{~m}$ a.s.l. In the specimens studied the chromosome number $2 \mathrm{n}=20$ was established. Prior to the present investigations the same chromosome number was found from various areas (data summarized by Bolkhovskikh et al. 1969, Má jovský et al. 1970a).

Rumex confertus Willd., $2 \mathrm{n}=60$ (Fig. 2)

Ruderal species occuring mainly along roadsides and railways; spreading westwards. The studied material was collected in Skomielna Biała (roadside). This species is varied as regards karyology. The number $2 \mathrm{n}=60$ was found in the studied material; it is in accordance with data given by Menšikova (1964, cit. acc. Bolkhovskikh et al. 1969). On the other hand, $2 \mathrm{n}=38$ (T s chermak-Woess and Doležal 1953) and $2 \mathrm{n}=40$ (Löve and Löve 1961, Menšikova l.c.) were found. The highest number $2 \mathrm{n}=100$ was reported by Mulligan (in L öve 1969) from Rumania - Botanical Garden, Cluj.

\section{CHENOPODIACEAE}

\section{Atriplex nitens Schrk., $2 \mathrm{n}=18$ (Fig. 3)}

Widespread in lowland but sporadic at lower altitudes, on ruderal places. Investigated material was collected in Warszawa, Kinowa street, on disturbed ground. The chromosome number $2 \mathrm{n}=18$ agrees with previous results from various areas (data summarized by Bolkhovskikh et al. 1969, Májovský et al. 1970a).

\section{CARYOPHYLLACEAE}

Silene dichotoma Ehrh., $2 \mathrm{n}=24$ (Fig. 4)

Here and there on lowland and at lower mountain altitudes up to $1000 \mathrm{~m}$ a.s.l., mainly as weed in clover fields. Specimens for study were collected in Kościelisko-Wojdyłówka (Subtatric Region), $970 \mathrm{~m}$ a.s.l. in clover field. The chromosome number $2 \mathrm{n}=24$ was established. The 

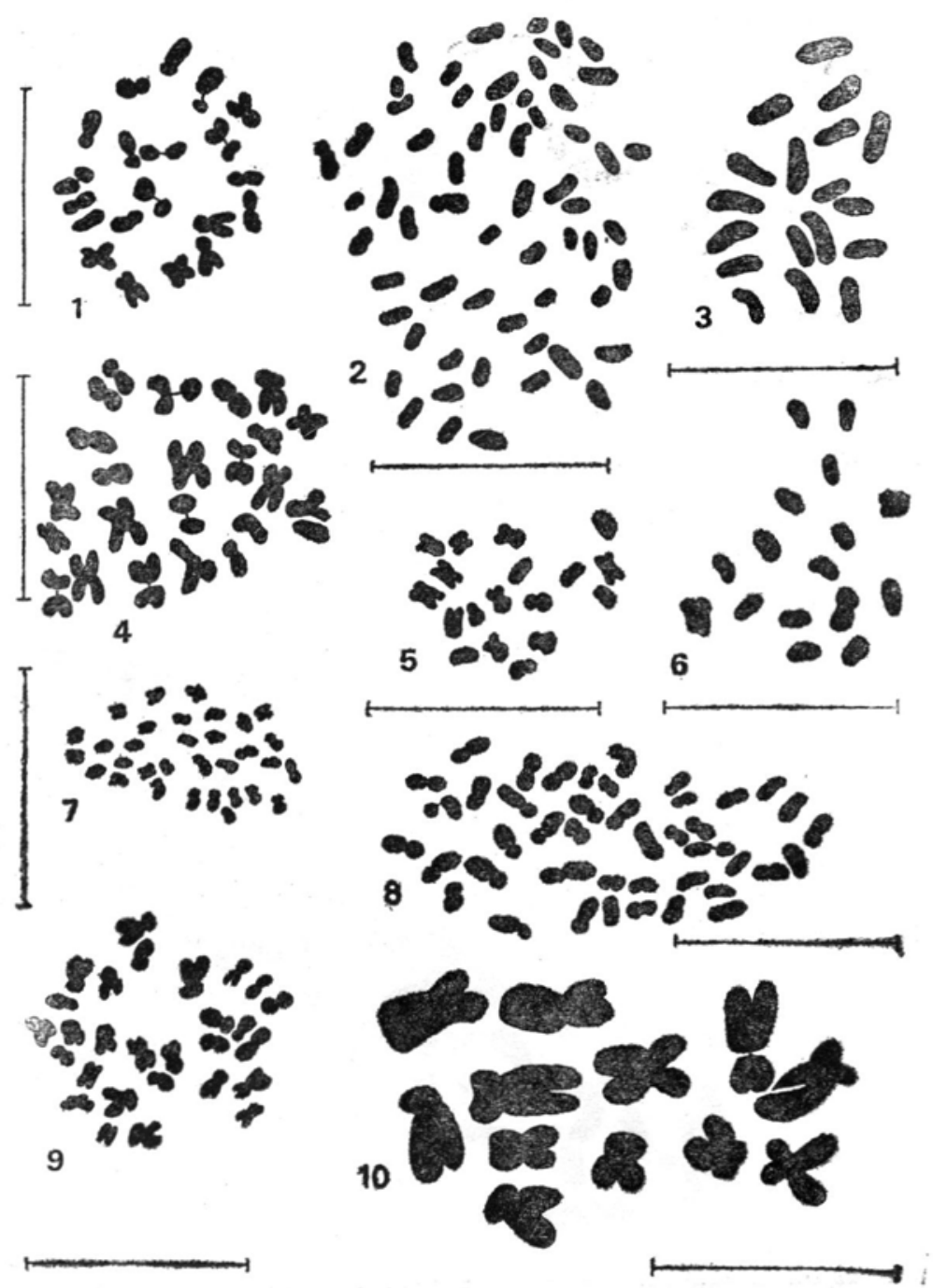

Figs. 1-10. Root-tip metaphases of: $1-$ Rumex alpinus $2 \mathrm{n}=20,2-$ Rumex confertus $2 \mathrm{n}=60,3-$ Atriplex nitens $2 \mathrm{n}=18,4-$ Silene dichotoma $2 \mathrm{n}=24$, $5-$ Spergula maxima $2 \mathrm{n}=18,6-$ Barbarea intermedia $2 \mathrm{n}=19,7-$ Rorippa amphibia $2 \mathrm{n}=32,8-$ Malva moschata $2 \mathrm{n}=42.9-$ Geranium pyrenaicum $2 \mathrm{n}=$ $=28,10-$ Crepis paludosa $2 \mathrm{n}=12$. Scale $-10 \mu \mathrm{m}$ 


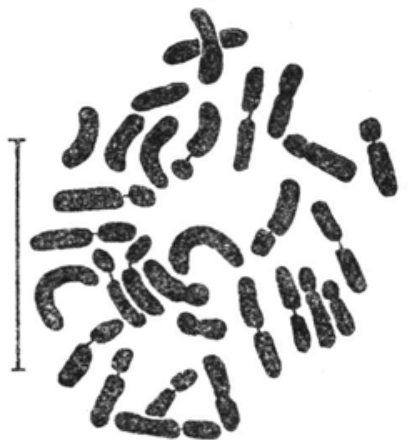

11
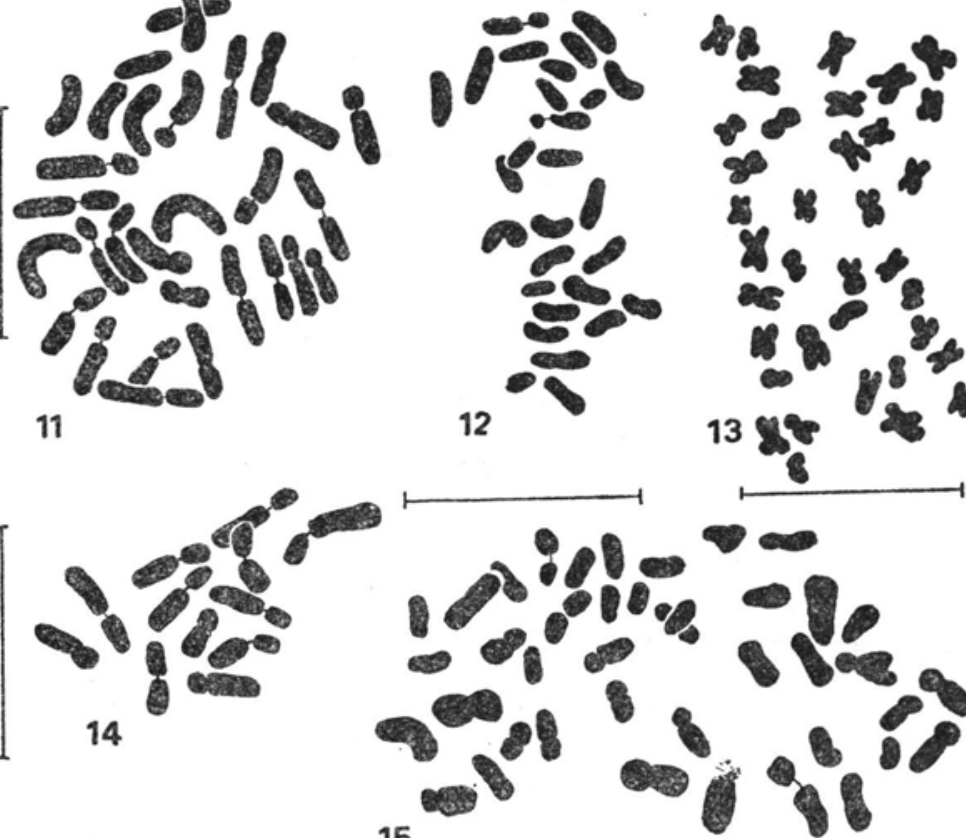

13

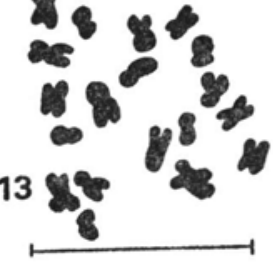

$\rightarrow \infty$

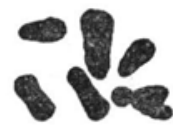

15

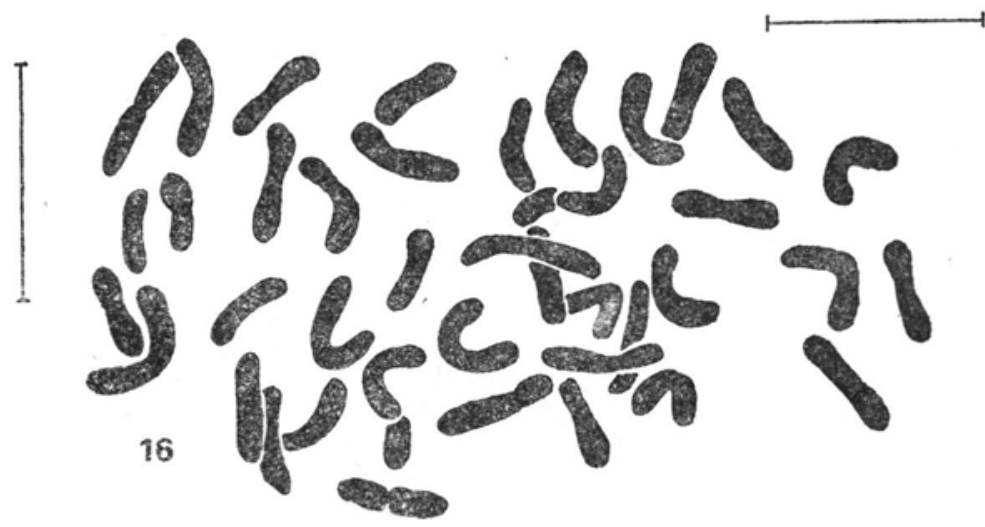

Figs. 11-16. Root-tip metaphases of: $11-$ Echinops sphaerocephalus $2 \mathrm{n}=30,12-$ Gnaphalium hoppeanum $2 \mathrm{n}=28,13$ - Iva xanthifolia $2 \mathrm{n}=36,14-$ Leontodon autumnalis $2 \mathrm{n}=12,15-$ Festuca arundinacea $2 \mathrm{n}=42,16-$ Avena fatua $2 \mathrm{n}=$ $=42$. Scale $-10 \mu \mathrm{m}$ 
same number was reported by many authors from other areas (data summarized by Bolkhovskikh et al. 1969, Májovský et al. $1970 \mathrm{a}$ - from Slovakia, D voř a k and D a dák ová 1976 - from Moravia, as well as Kožuharov and Petrova in Löve $1974 \mathrm{~b}$ - from Bulgaria).

Spergula maxima Weihe (= S. arvensis L. ssp. maxima (Weihe) M. K. em. Pawł.), $2 n=18$ (Fig. 5)

All over Poland as a flax-weed, in the mountains up to $1000 \mathrm{~m}$ a.s.l. Recently becoming very rare because of its rapid extinction connected with cleaning of flax seed material. This taxon has been included into $S$. arvensis s. lato by many authors. The studied specimens were collected from two localities: as a weed in crop fields, village Poronin-Frąckówka, near Zakopane (Subtatric Region) $820 \mathrm{~m}$ a.s.l., and Zakopane-Guty $800 \mathrm{~m}$ a.s.l. Differences between $S$. maxima and typical $S$. arvensis s. str. are presented in Table 1 . The chromosome number $2 n=18$ was found. In available literature the present authors did not find any mention of chromosome numbers of $S$. maxima. In all probability part of the data dealing with chromosome numbers of $S$. arvensis (data summarized by Bolkhovskikh et al. 1969, Gadella and Kliphuis 1973) concern $S$. maxima.

Table 1

Differences between Spergula maxima and S. arvensis s. str.

\begin{tabular}{|l|c|c|}
\hline Characters & S. maxima & S. arvensis \\
\hline Diameter of seeds & $1.5-2.0 \mathrm{~mm}$ & $0.8-1.2 \mathrm{~mm}$ \\
Height of stem & $40-100 \mathrm{~cm}$ & $10-40(50) \mathrm{cm}$ \\
Glandularity & no glands \\
or sparcely & glandular & \\
$\begin{array}{c}\text { Length of lower and } \\
\text { median leaves }\end{array}$ & $4-8 \mathrm{~cm}$ & $2-4 \mathrm{~cm}$ \\
\hline
\end{tabular}

\section{CRUCIFERAE}

\section{Barbarea intermedia Boreau, $2 \mathrm{n}=16$ (Fig. 6)}

This species has been recently found in Poland in some localities at lower altitudes in the Western Carpathians (M i r e k 1983). Mostly on wet open places and roadsides. The plants for the present studies were collected in Kościelisko-Wojdyłówka near Zakopane (Subtatric Region), $970 \mathrm{~m}$ a.s.l. on disturbed ground. The chromosome number confirms the count of Manton (1932).

Rorippa amphibia (L.) Bess., $2 \mathrm{n}=32$ (Fig. 7)

Very common on lowland along rivers, streams and near ponds. The plant material originated from two localities: Miechów-Pińczów district, 
village Chotel Czerwony, pond banks, and Wiślica, riverside. In the specimens studied the chromosome number $2 \mathrm{n}=32$ was established. The same number was reported by Löve and Löve (1942), Gadella and Kliphuis (1968), Javůrková-Kratochvilová and Tomšovic (1972), Má jovský et al. (1974b). Howard (1947) and $Q$ ueiros (1973b) give the number $2 \mathrm{n}=16$, whereas $\mathrm{How}$ ard (1953) and Jonsell (1968) reported two chromosome numbers $2 \mathrm{n}=$ $=16$ and 32 .

\section{MALVACEAE}

\section{Malva moschata L., 2n $=42$ (Fig. 8)}

Naturalized from gardens, especially in Northern Poland, Lower Silesia, and locally at lower altitudes in the Carpathians, already well established. The plant specimens originated from Zakopane, $925 \mathrm{~m}$ a.s.l., disturbed places, near railway station. D a vie (1933) and Delay (1947, cit. acc. Bolkhovskikh et al. 1969) found $2 \mathrm{n}=40-44$, while S vens son-Stenar (1925), Skovsted (1935), Murin and Májovský (in Löve 1978b) and Loon (in Löve 1980b) reported $2 \mathrm{n}=$ $=40$. In Polish material $2 \mathrm{n}=40$ was also established.

\section{GERANIACEAE}

Geranium pyrenaicum Burm. fil. $2 \mathrm{n}=28$ (Fig. 9)

Throughout most of Poland, but more frequent only in the South-West and South of Poland. Probably only adventive, but well established. It occurs in the Carpathians and in the Sudetes. Usually up to $600 \mathrm{~m}$ a.s.l. The investigated specimens originated from Zakopane, $805 \mathrm{~m}$ a.s.l., city dump. In the present work the chromosome number $2 \mathrm{n}=28$ was established. It is in accordance with some former results (Warburg 1938, cit. acc. Bolkhovskikh et al. 1969, Loon et al. 1971 from France). However, different numbers were found by Chatterjee and Sharma (in Moore 1973) - $2 \mathrm{n}=20$, and Májovský et al. $(1974 b)-2 n=26$ from Slovakia. The latter number was previously reported in Polish material from two localities by $\mathrm{Skalinska}$ et al. (1978).

\section{LABIATAE}

Ballota nigra L. ssp. nigra, $2 \mathrm{n}=22$

Widespread on lowland, but rare and only at lower altitudes in the mountains. In ruderal, nitrophilous communities of the Eu-Arction alliance, mainly Leonuro-Arctietum and Balloto-Chenopodietum. The plant material originated from the village Szczepanowice near Miechów 
(among tall herbs and on roadside). In respect of chromosome number it is a rather uniform species. $2 \mathrm{n}=22$ was reported in previous studies from Bulgaria (Markova and Thu, in L ö ve 1974a), from Corsica (Hassal, in Löve 1978a) and from British Isles (Morton 1973) for ssp. foetida. On the other hand, $2 \mathrm{n}=20$ is mentioned by Strid and Franzén (in Löve 1981) from Greece.

\section{COMPOSITAE}

\section{Anthemis cotula L., $2 \mathrm{n}=18$}

Not rare on various ruderal habitats on lowland and at lower altitudes in the mountains. The studied material was collected in Słomniki near Kraków, on a ruderal site. The number $2 \mathrm{n}=18$ agrees with that reported previously from other territories (data summarized by Bolkhovskikh et al. 1969, Strid 1971 from Albania, Queiros 1973a from Portugal, Löve and K jellqvist 1974 from Spain, Kuzmanov and Thin in Löve 1980a from Bulgaria).

\section{Crepis paludosa (L.) Mnch., $2 \mathrm{n}=12$ (Fig. 10)}

Widespread all over Poland, but less frequent on lowland. In the Tatra Mts. up to $1750 \mathrm{~m}$ a.s.l. Especially abundant in moist tall herb communities and in the associations: Valeriano-Caricetum flavae and Caltho-Alnetum. The plant material originated from wet meadow growing on calcareous ground between. Działoszyce and Chmielów (Miechów-Pińczów district). In the specimens studied the chromosome number $2 \mathrm{n}=12$ was established. It is in accordance with the previous results of many authors (Bolkhovskikh et al. 1969, Má jovský et al. $1970 \mathrm{~b}, \mathrm{D}$ vořák and D a dák ová 1977).

\section{Echinops sphaerocephalus L., $2 \mathrm{n}=30$ (Fig. 11)}

Sometimes cultivated as a honey-yielding plant and locally naturalized in ruderal habitats. The species is said to be characteristic of the alliance Onopordion. Material for the study was collected on a grassy slope at roadside between Wesoła and Słomniki, near Kraków. In the Polish material $2 \mathrm{n}=30$ was found. This number confirms the counts of Moore and Frankton (1962). On the other hand, the chromosome number $2 \mathrm{n}=32$ was reported by $\mathrm{H}$ indáková and Činčura (1967).

\section{Erigeron acer $\mathrm{L} ., 2 \mathrm{n}=18$}

Widespread all over Poland. Common on rocky and stony places, dry slopes, roadsides and pastures. The karyologically studied species were collected in Zakopane, $860 \mathrm{~m}$ a.s.l. on a stony site, at Bulwary Słowackiego. The chromosome number $2 \mathrm{n}=18$ confirms the previous data reported by many authors from various areas (Bolkhovskikh et al. 1969, Fernandes and Queiros 1971, Fritisch, in Löve 1973, 
Queiros 1973a, Mort on 1977). Siljak-Yakovlev (in L öve 1981) established for E. acer diploid and tetraploid numbers $(2 \mathrm{n}=18$ and 36$)$ for specimens from Yugoslavia. By contrast Tischler (1934) found a different chromosome number $2 \mathrm{n}=27$ for the plants from Schleswig-Holstein.

Gnaphalium hoppeanum Koch $2 \mathrm{n}=28$ (Fig. 12)

High-montane species. On territory of Poland only in the Tatra Mts. (calcareous rocks and crevices); from lower mountain zone up to alpine zone (1150-2130 $\mathrm{m}$ a.s.l.). The investigated material was collected in Mała Łąka Valley (Western Tatra Mts.), $1280 \mathrm{~m}$ a.s.l., on calcareous rocks. The number $2 \mathrm{n}=28$ was established in plants from Poland probably for the first time. In the available literature the present authors did not find any mention of chromosome numbers for this species.

Iva xanthifolia Nutt., $2 \mathrm{n}=36$ (Fig. 13)

On lowland not rare, lacking in the mountains. Usually in various ruderal habitats, largely along railways, and open disturbed places. Plant specimens for karyological studies were collected in Warszawa, Kinowa street, on a disturbed, ruderal place. In this species two chromosome numbers $2 \mathrm{n}=28$ and 36 are known. The first number was hitherto reported only by $\mathrm{Mulli}$ g a $\mathrm{n}$ (1959) from Canada, the latter established also in the present paper is in accordance with the previous results obtained by several authors (M u lliga n 1959, Ferák ová 1966, 1968, 1972, Má jovsk ý et al. 1974a).

\section{Leontodon autumnalis L., $2 \mathrm{n}=12$ (Fig. 14)}

Very common species all over Poland largely on meadow, pastures and trampled places. In Tatra Mts. up to $1830 \mathrm{~m}$ a.s.l. The material originated from Szczepanowice (Miechow-Pińczów district), fresh meadow near Szreniawa river. In plants from Poland the chromosome number $2 \mathrm{n}=12$ was established. The same chromosome number was found by many authors (data sumarized by Bolkhovskikh et al. 1969, as well as Gadella and Kliphuis 1970, La a ne 1969, 1971, R ousi 1973, Edmonds et al. 1974, Löve and $\mathrm{Kjellqvist} \mathrm{1974).} \mathrm{On}$ the other hand, Vaarama (in Löve and Löve 1948) reported $2 \mathrm{n}=$ $=24$. The number $\mathrm{n}=16$ given for $L$. autumnalis var. autumnalis (P o w e ll et al. 1974) seems doubtful.

\section{GRAMINEAE}

Festuca arundinacea Schreb., $2 \mathrm{n}=42$ (Fig. 15)

Alluvial meadows, margins and roadsides on lowland; less frequent at lower altitudes in the mountains. The specimens studied were collected in Szczepanowice (Miechów-Pińczów district), on railway tracks. In plants from Poland the chromosome number $2 n=42$ was found. The 
same number was established by Polý a (1950), Löve and Löve (1956), Uhríková and Májovský (in Löve 1977). Karyological studies hitherto carried out within the species revealed its great differentiation in this respect. Several chromosome numbers were reported in previous studies: $2 \mathrm{n}=28,42$ (S t ählin 1929, Chandrasekharan et al. 1972), $2 \mathrm{n}=28,42,70$ ( $\mathrm{M} \mathrm{alik}$ and $\mathrm{Th}$ om a s 1966), $2 \mathrm{n}=42,56,63$, 70 (Borril et al. 1971), however, the number $2 \mathrm{n}=42$ seems to be most frequent. Accesory chromosomes were also observed in this species (data summarized by Bolkhovskikh et al. 1969, Chandrasekharan and Thom as 1971).

Avena sativa L., $2 \mathrm{n}=42$

Cultivated on lowland as well as in lower mountain zone. Sometimes as a weed on ruderal places. Specimens for the present studies were collected from four habitats: Jerzmanowice near Kraków, Biała Góra reservation near Miechów, Rózino near Włocławek, Mikołajki (Masuria). This species is uniform as regards karyology; the hexaploid number was found by many authors from various areas (data summarized by B olkhovskikh et al. 1969, as well as Rajhathy and Thomas 1974, cit. acc. $\mathrm{B}$ a u $\mathrm{m}$ 1977). The same number was established in the present work.

A. fatua L., $2 \mathrm{n}=42$ (Fig. 16)

Widespread as a weed in cultures of wheat, oat, rye as well as on ruderal places. In mountains (Gorce Mts.) up to $900 \mathrm{~m}$ a.s.l. The plants originated from four habitats: Słomniki near Kraków, Rabsztyn near Olkusz, Biała Góra reservation near Miechów, Mikołajki (Masuria). In this species only one chromosome number was hitherto found, $2 \mathrm{n}=42$ (data summarized by Bolkhovskikh et al. 1969, Rajhathy and Thomas 1974, cit. acc. B a um 1977). The same number was found in the examined material from Poland.

\section{REFERENCES}

B a um B., 1977. Oats: wild and cultivated. Monograph No 14: 1-463.

Bolkhovskikh Z., Grif V., Matveyeva T., Zakharyeva O., 1969. Chromosome numbers of flowering plants. Izd. Nauka, Leningrad.

Borril M., Tyler B., Lloyd-Jones M., 1971. Studies in Festuca. I. A çromosome atlas of bovinae and scariosae. Cytologia 36: 1-14.

Chandrasekharan P., Levis E., Borril M., 1972. Studies in Festuca. II. Fertility relationships between species and sections Bovinae and Scariosae, and their affinities with Lolium. Genetica 43: 375-386.

Chandrasekharan P., Thomas H., 1971. Studies in Festuca. VI. Chromosome relationships between Bovinae and Scariosae. Z. Pflanzenzücht. 66: 76-86.

Davie H., 1933. Cytological studies in the Malvaceae and related families. J. Genet. 28: 33-67.

Dvořák F., Da dáková B., 1976. Cytotaxonomic studies of some species of southern Moravian flora. Folia 17: 5-107. 
Dvořák F., Da dáková B., 1977. Karyotypes on some species of the genus Crepis L. Biologia (Bratislava) 32: 747-757.

Edmonds J. M., Sell P., Walters S., 1974. Some British chromosome counts in the Compositae sub-family Cichorioideae. Watsonia 10: 159-161.

Feráková V., 1966. Přispevek k rozšireniu a karyologii Iva xanthifolia Nutt. Biologia (Bratislava) 21: 612-616.

Feráková V., 1968. Weitere Bemerkungen zur Verbreitung und Karyologie von Iva xanthifolia. Nutt. Biologia (Bratislava) 23: 317-319.

Feráková V., 1972. Bemerkungen zur Flora der Umgebung der Stadt Hlohovec in der Slowakei. III. Erganzungen. Acta Fac. Rerum Nat. Univ. Comenianae Bot. 20: 149-158.

Fernandes A., Queiros M., 1971. Contribution a la connaissance cytotaxinomique des Spermatophyta du Portugal. II. Compositae. Bol. Soc. Brot. 45 (ser. 2): 5-122.

Frey L., Mirek Z., Mizianty M., 1977. Contribution to the chromosome numbers of Polish vascular plants. Fragm. Flor. .Geobot. 23: 317-325.

Frey L., Mizianty M., Mirek Z., 1981. Chromosome numbers of Polish vascular plants. Fragm. Flor. Geobot. 27: 581-590.

Ga della Th. W. J., Kliphuis E., 1968. Chromosome numbers of flowering plants in the Netherlands. 4. Proc. Roy. Netherlands Acad. Sci. Ser. C 71: 168-183.

Gadella Th. W. J., Kliphuis E., 1970. Chromosome studies in some flowering plants collected in the French Alps (Haute Savoie). Rev. Gen. Bot. 77: 487-497.

Gadella Th. W. J., Kliphuis E., 1973. Chromosome numbers of flowering plants in the Netherlands. 6. Proc. Roy. Netherlands Acad. Sci. Ser. C 76: 303-311.

Hin dákova M., Cinčura F., 1967. Angaben über die Zahl und Morphologie der Chromosomen einiger Pflanzenarten aus dem Territorium der Ostslowakei. 1. Acta Fac. Rerum Nat. Univ. Comenianae Bot. 14: 181-227.

How a r d H. W., 1947. Chromosome numbers of British species of the genus Rorippa Scop. Nature (London) 159: 66.

How a r d H. W., 1953. Induced and natural polyploid in Nasturtium and Rorippa. Proc. VII Intern. Bot. Congr. pp. 331-332.

J a vůrková-Kratochvilová V., Tomšovic P., 1972. Chromosome study of the genus Rorippa Scop. em. Reichenbach in Czechoslovakia. Preslia 44: 140-156.

J onsell B., 1968. Studies in the North-West European species of Rorippa s. str. Symb. Bot. Upsal. 19: 16-20.

L a a n M. H., 1969. Meiosis and structural hybridity in some Norwegian plant species. Blyttia 27: 141-173.

L a a n e M. H., 1971. Chromosome numbers in Norwegian vascular species. Blyttia 29: $229-234$.

Loon J. Chr., Ga della Th. W. J., Kliphuis E., 1971. Cytological studies in some flowering plants from Southern France. Acta Bot. Neerl. 20: 157-166.

Löve A., 1969. IOPB Chromosome number reports. 20. Taxon 18: 213-221.

Löve A., 1973. IOPB Chromosome number reports. 41. Taxon 22: 459-464.

Löve A., 1974a. IOPB Chromosome number reports. 43. Taxon 23: 193-196.

Löve A., 1974b. IOPB Chromosome number reports. 44. Taxon 23: 373-380.

Löve A., 1977. IOPB Chromosome number reports. 55. Taxon 26: 257-274.

Löve A., 1978a. IOPB Chromosome number reports. 59. Taxon 27: 53-61.

Löve A., 1978b. IOPB Chromosome number reports. 61. Taxon 27: 375-392.

Löve A., 1980a. IOPB Chromosome number reports. 69. Taxon 29: 703-730. 
Löve A., 1980b. IOPB Chromosome number reports. 68. Taxon 29: 533-547.

Löve A., 1981. IOPB Chromosome number reports. 73. Taxon 30: 829-861.

Löve A., Kjel1qvist E., 1974. Cytotaxonomy of Spanish plants. 4. Dicotyledons: Caesalpiniaceae-Asteraceae. Lagascalia 4: 153-211.

Löve A., Löve D., 1942. Chromosome numbers of Scandinavian plant species Bot. Not. 1942: 19-59.

Löve A., Löve D., 1948. Chromosome numbers of Northern plant species. Repts. Dept. Univ. Inst. Appl. Sci., Ser. B. 3: 9-131.

Löve A., Löve D., 1956. Cytotaxonomical conspectus of the Icelandic flora. Acta Horti Gothob. 20: 65-291.

Löve A., Löve D., 1961. Chromosome numbers of Central and North-West European plant species. Opera Botanica 5: 1-581.

Májovský J. et al., 1970a. Index of chromosome numbers of Slovakian flora. 1. Acta Fac. Rerum Nat. Univ. Comenianae Bot. 16: 1-26.

Májovský J. et al., 1970b. Index of chromosome numbers of Slovakian flora. 2. Acta Fac. Rerum Nat. Univ. Comenianae Bot. 18: 45-60.

Májovský J. et al., 1974a. Index of chromosome numbers of Slovakian flora. 3. Acta Fac. Rerum Nat. Univ. Comenianae Bot. 22: 1-20.

Májovský J. et al., 1974b. Index of chromosome numbers of Slovakian flora. 4. Acta Fac. Rerum Nat. Univ. Comenianae Bot. 23: 1-23.

Malik C. P., Thomas P. T., 1966. Karyotypic studies in some Lolium and Festuca species. Caryologia 19: 167-196.

M a n t on I., 1932. Introduction to the general cytology of the Cruciferae. Ann. Bot. 46: $509-556$.

M irek Z., 1983. Barbarea intermedia Boreau i B. verna (Miller) Aschers. - dwa nowe gatunki dla flory Polski. Fragm. Flor. Geobot. 29: (in press).

Mizianty M., Frey L., Mirek Z., 1981. Contribution to the knowledge on the chromosome numbers of Polish vascular plants. Fragm. Flor. Geobot. 27: 19-29.

M o ore R. J., 1973. Index to plant chromosome numbers 1967-1971. Regnum Veg. 90: 1-539.

Moore R. J., Frankton C., 1962. Cytotaxonomic studies in the tribe Cynareae (Compositae). Can. J. Bot. 40: 281-299.

Morton J. K., 1973. A cytological study of the British Labiatae. Watsonia 9: 239-246.

Morton J. K., 1977. A cytological study of the Compositae (excluding Hieracium and Taraxacum) of the British Isles. Watsonia 11: 211-223.

Mulligan G., A., 1959. Chromosome numbers of Canadian weeds. 2. Can. J. Bot. 37: 81-92.

Polý a L., 1950. Chromosome numbers of Hungarian plants. 2. Ann. Biol. Univ. Debreceniensis 1: 46-56.

Powell A. M., Kyhos D. W., Raven P. H., 1974. Chromosome numbers in Compositae. 10. Amer. J. Bot. 61: 909-913.

Queiros M., 1973a. Contribuição para o conhecimento citotaxonómico das Spermatophyta de Portugal. 2. Compositae, supl. 1. Bol. Soc. Brot. 47 (Ser. 2): 299-314.

Queiros M., 1973b. Contribuição para o conhecimento citotaxonómico das Spermatophyta de Portugal. 9. Cruciferae. Bol. Soc. Brot. 47 (Ser. 2): 315-335.

Rousi A., 1973. Studies on the cytotaxonomy and mode of reproduction of Leontodon (Compositae). Ann. Bot. Fenn. 10: 201-215.

Skalińska M., Pogan E., Czapik R., 1978. Further studies in chromosome numbers of Polish Angiosperms. Acta Biol. Cracov. Ser. Bot. 21: 31-63, 
Skovsted A., 1935. Chromosome numbers in the Malvaceae. 1. J. Genet. 31: 263-296.

Stählin A., 1929. Morphologische und cytologische Untersuchungen an Gramineen. Pflanzenbau 1: 230-397.

Strid A., 1971. Chromosome numbers in some Albanian Angiosperms. Bot. Not. 124: $490-496$.

S ven s s on-S tenar H., 1925. Embryologische Studien. 1. Akad. Abhand. Uppsala, Appelbergs Boktryckeri Aktiebolag 1-197.

Tischler G., 1934. Die Bedeutung der Polyploidie für die Verbreitung der Angiospermen. Bot. Jb. 67: 1-36.

T schermak-Woess E., Doležal R., 1953. Durch Seitenwurzelbildung induzierte und spontane Mitosen in den Dauergeweben der Wurzel. Ósterr. Bot. Z. 100: $358-405$.

Liczby chromosomów polskich roślin naczyniowych

\section{Streszczenie}

W pracy zostały podane liczby chromosów 20 gatunków roślin naczyniowych. Są to przeważnie dane nowe dla Polski, a liczba chromosomów $2 n=28$ u Gnaphalium hoppeanum Koch. jest podana prawdopodobnie po raz pierwszy. Większość badanych roślin jest rzadka lub bardzo rzadka na terenie kraju np. Barbarea intermedia, Echinops sphaerocephalus, Geranium pyrenaicum, Iva xanthifolia, Malva moschata, Spergula maxima. Dlatego materiał do badań zbierano tylko z jednego stanowiska. 